\title{
Seasonal and spatial variations in the chemistry of a High Arctic supraglacial snow cover
}

\author{
Martin SHARP, ${ }^{1}$ Mark SKIDMORE, ${ }^{1}$ Peter NIENOW ${ }^{2}$ \\ ${ }^{1}$ Department of Earth and Atmospheric Sciences, University of Alberta, Edmonton, Alberta T6G 2E3, Canada \\ E-mail: martin.sharp@ualberta.ca \\ ${ }^{2}$ Department of Geography and Topographic Science, University of Glasgow, Glasgow G12 8QQ, Scotland
}

\begin{abstract}
This paper describes the physical and chemical properties of the snowpack on John Evans Glacier, Ellesmere Island, Canadian Arctic Archipelago, and investigates the controls on snowpack solute concentrations and atmospheric deposition. The snowpack contains three layers that are traceable across the whole glacier. These represent fall accumulation that has been metamorphosed to depth hoar, winter accumulation mixed with snow reworked by wind from the underlying depth hoar, and spring accumulation mixed with wind-reworked snow. The seasonal cycle in snow chemistry closely reflects changes in the composition of the atmospheric aerosol at Alert, with some modification of $\mathrm{NO}_{3}{ }^{-}$concentrations by post-depositional processes. Mean water-weighted solute concentrations in the snowpack are largely independent of accumulation, while atmospheric deposition tends to increase with accumulation. This suggests that, for most species, wet deposition is the dominant depositional process throughout the year. However, concentrations of $\mathrm{Ca}^{2+}$ and $\mathrm{K}^{+}$increase with both accumulation and elevation, implying an enhanced input from dry deposition of soil dust above $800 \mathrm{~m}$ elevation. Concentrations of $\mathrm{SO}_{4}{ }^{2-}$ are inversely related to accumulation, especially in the winter layer, suggesting a significant input from non-precipitating events, such as dry deposition or riming, during this period of very limited snowfall.
\end{abstract}

\section{INTRODUCTION}

Records of past atmospheric deposition can be preserved in the firn and ice of non-temperate glaciers. These records provide insight into changes in the chemical composition of the atmosphere (Neftel and others, 1985; Mayewski and others, 1986; Legrand and others, 1988) and into the nature and intensity of the atmospheric circulation systems which deliver aerosol to the site of deposition. Such records may be particularly valuable for reconstructing past climates (Mayewski and others, 1993, 1994) and the history of air pollution (Barrie and others, 1985; Wagenbach and others, 1988; Boutron, 1995). Where atmospheric chemistry varies on subannual time-scales, annual cycles of solute deposition may be preserved in glacier ice, providing stratigraphic markers which allow dating of ice cores and reconstruction of changes in accumulation rate (Mayewski and others, 1987; Steffensen, 1988; Davidson and others, 1989; Wake, 1989; Jonsson and Hansson, 1990).

Long ice-core records have been recovered from Devon, Agassiz, Meighen and Penny Ice Caps in the Canadian Arctic (Koerner and Paterson, 1974; Koerner, 1977; Fisher and others, 1995; Grumet and others, 1998). However, until recently there have been few detailed studies of snow chemistry in this region (Koerner and Fisher, 1982; Goto-Azuma and others, 1997). Such studies are needed to define the seasonal cycle of atmospheric deposition to ice caps, and to provide information about spatial variations in snow chemistry that allow assessment of how spatially representative are ice-core sites, and how significant are temporal changes in chemistry recorded in ice cores. Here we present the results of a detailed study of the seasonal and spatial variations in the chemistry of the snow cover of a large polythermal glacier on eastern Ellesmere Island. The study was undertaken as part of an effort to reconstruct the recent accumulation history of the glacier from measurements on shallow ice cores. These demanded knowledge of the seasonal cycle in snowpack chemistry to assist dating of the ice cores by identification of annual layers defined by variations in ice chemistry.

The specific objectives of this study were to:

(i) describe the physical characteristics of the snowpack and their variation with elevation;

(ii) establish the seasonal pattern of snow accumulation, its variation with elevation, and its relationship to the physical characteristics of the snowpack;

(iii) characterize the seasonal and spatial variability in the major-ion chemistry of the snowpack and its relationship to the physical characteristics of the snowpack;

(iv) compare seasonal changes in snow chemistry with seasonal changes in the chemistry of the atmospheric aerosol as determined from a 15 year time series of measurements at Alert, on the northern tip of Ellesmere Island (Sirois and Barrie, 1999); and

(v) investigate the influence of surface elevation and snow accumulation on the mean water-weighted (MWW) concentrations of major ions within the snowpack, and on atmospheric deposition of major ions. 

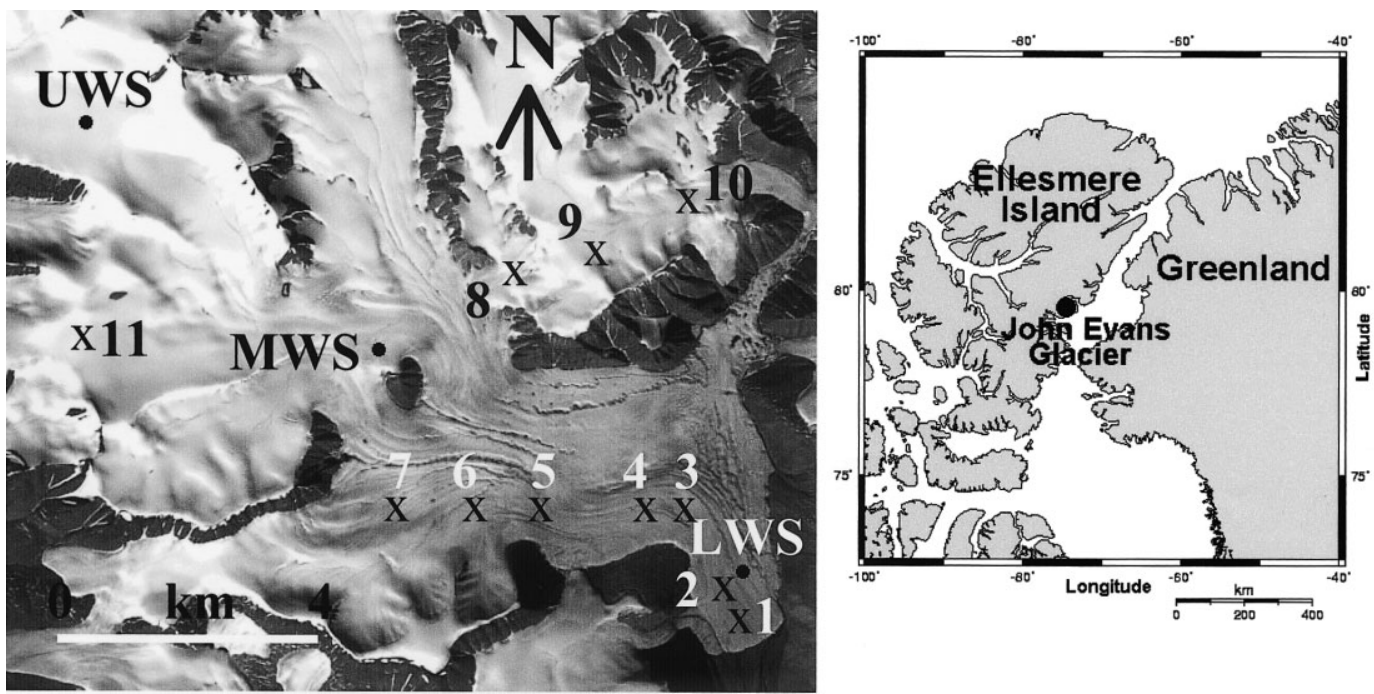

Fig. 1. (a) July 2000 Landsat 7 image of John Evans Glacier. Locations of the three weather stations (LWS, MWS and UWS) are shown. Snow-pit sites are numbered according to their elevation (in hundreds of metres). (b) Map showing the location of the glacier on Ellesmere Island.

\section{FIELD SITE}

John Evans Glacier is located at the head of Allman Bay, on the eastern coast of Ellesmere Island, Nunavut, Canada $\left(79^{\circ} 40^{\prime} \mathrm{N}, 74^{\circ} 23^{\prime} \mathrm{W}\right.$; Fig. 1). It has an area of $165 \mathrm{~km}^{2}$ and spans an elevation range of $100-1500 \mathrm{~m}$. The maximum ice thickness approaches $400 \mathrm{~m}$ near the equilibrium line, which is located at $750-800 \mathrm{~m}$ a.s.l. For the period June 1996-June 1997, the mean annual air temperature at an automatic weather station located at an elevation of $250 \mathrm{~m}$ on the glacier was $-14.7^{\circ} \mathrm{C}$. Fifteen-metre ice temperatures in the accumulation area range from $-10^{\circ}$ to $-15^{\circ} \mathrm{C}$. The glacier is composed primarily of ice at sub-freezing temperatures, but the melting point is reached at the bed over much of the ablation area and there is a thin $(<40 \mathrm{~m})$ basal layer of temperate ice in the lower ablation area (Copland and Sharp, 2001). Catchment geology is dominated by limestones, dolostones and anhydrite/gypsum of Cambrian, Ordovician and Silurian age (Kerr, 1972).

\section{FIELD METHODS}

Sampling was conducted in May 1995. Snow pits were excavated at $100 \mathrm{~m}$ elevation intervals between 100 and 1100 m a.s.l. (Fig. 1). Pits were dug to the level of the 1994 summer surface with a Teflon-coated aluminium shovel. The physical stratigraphy of the snowpack was described prior to sampling. Snow density was measured on non-continuous samples (normally $0.0001 \mathrm{~m}^{3}$, but $0.00001 \mathrm{~m}^{3}$ where layers were $<0.06 \mathrm{~m}$ thick) collected from each distinct layer. Crystal size and shape were described after viewing under a hand lens. Snow temperature was measured at $10 \%$ depth intervals using dial thermometers. Water equivalent accumulation at each site was determined by summing the products of density and layer thickness for all layers in the snowpack.

For chemical sampling, a second face immediately adjacent to that used for description of the physical stratigraphy was cleaned by removing at least $0.1 \mathrm{~m}$ of snow with a plastic scoop. A worker wearing clean plastic gloves conducted vertically continuous sampling on a layer-by-layer basis. Samples were transferred to clean plastic bags using the plastic scoop and double wrapped.
At the field camp, samples were melted inside the sealed sample bags. $\mathrm{pH}$ and electrical conductivity of unfiltered samples were measured immediately after melting. $\mathrm{pH}$ was measured with a Ross Sure-flow electrode and Orion 290A pH meter, using Orion low-ionic-strength buffers of pH 4.10 and 7.01. Prior to analysis, samples were treated with $\mathrm{pH}$ ionic-strength adjuster solution. Accuracy is $\pm 0.1 \mathrm{pH}$ units. Electrical conductivity was measured with a Cole Palmer model 1500-32 conductivity meter, calibrated with standards of 1 and $10.4 \mu \mathrm{S} \mathrm{cm}^{-1}$. Accuracy is $\pm 0.4 \mu \mathrm{S} \mathrm{cm}^{-1}$. The remainder of each sample was filtered under vacuum through $0.45 \mu \mathrm{m}$ cellulose nitrate filter papers. Filtration equipment and sample bottles were triple rinsed with sample water before the final sample was collected. Separate $30 \mathrm{~mL}$ aliquots were collected for anion $\left(\mathrm{Cl}^{-}, \mathrm{NO}_{3}{ }^{-}, \mathrm{SO}_{4}{ }^{2-}\right)$ and cation $\left(\mathrm{Na}^{+}, \mathrm{K}^{+}, \mathrm{Ca}^{2+}, \mathrm{Mg}^{2+}\right.$ and $\left.\mathrm{NH}_{4}{ }^{+}\right)$analysis. The latter aliquot was acidified with $0.75 \mathrm{~mL} 1 \mathrm{M}$ methanesulphonic acid.

To determine the seasonal pattern of snow accumulation on the glacier, three automatic weather stations were established at elevations of $250 \mathrm{~m}$ (LWS), $850 \mathrm{~m}$ (MWS) and $1180 \mathrm{~m}$ (UWS) above sea level (Fig. 1). These stations operated continuously from May 1996 to May 2000. Changes in the thickness of the snowpack were monitored daily (at midnight) with a Campbell Scientific Ultrasonic Depth Gauge (UDG) attached to a CR-10 data logger.

\section{LABORATORY ANALYSIS}

Samples were stored at $4^{\circ} \mathrm{C}$ prior to analysis. Concentrations of major cations and anions were measured by ion chromatography on a Dionex DX-500 instrument. Detection limits $\left(\mu \mathrm{eq} \mathrm{L}{ }^{-1}\right)$ were: $\mathrm{Cl}^{-}=0.7, \mathrm{NO}_{3}{ }^{-}=0.3, \mathrm{SO}_{4}{ }^{2-}=$ $0.5, \mathrm{Na}^{+}=0.4, \mathrm{NH}_{4}{ }^{+}=0.6, \mathrm{~K}^{+}=0.25, \mathrm{Mg}^{2+}=0.75$ and $\mathrm{Ca}^{2+}=1.5$. For anions, both precision and accuracy were better than $\pm 6 \%$ at concentrations of $>3 \mu \mathrm{eq} \mathrm{L} \mathrm{L}^{-1}$, but $> \pm 10 \%$ at lower concentrations. For cations, both precision and accuracy were better than $\pm 8 \%$ at concentrations of $>2 \mu \mathrm{eq} \mathrm{L}{ }^{-1}$, but $> \pm 10 \%$ at lower concentrations.

Average charge balance errors $\left(\left(\Sigma^{+}-\Sigma^{-}\right) /\left(\Sigma^{+}+\Sigma^{-}\right)\right.$ $=+31.8 \% \pm 1 \mathrm{SD}$ of $32.5 \%)$ revealed a consistent excess of cations over anions, suggesting that the imbalance was due 
primarily to the presence of an unanalyzed species rather than to analytical error. There was a strong correlation between the cation excess $\left(\Sigma^{+}-\Sigma^{-} ; \mu \mathrm{eq} \mathrm{L}^{-1}\right)$ and the $\mathrm{Ca}^{2+}$ concentration:

$$
\left(\Sigma^{+}-\Sigma^{-}\right)=-2.77( \pm 0.88)+1.47( \pm 0.06) \mathrm{Ca}^{2+}
$$

$\left(r^{2}=0.84, p<0.001\right)$. This suggests that much of the error is attributable to $\mathrm{HCO}_{3}{ }^{-}$, which is commonly the counter-ion to the crustally derived fractions of cations such as $\mathrm{Ca}^{2+}$ and $\mathrm{Mg}^{2+}$. Given the magnitude of the imbalance, especially in the more concentrated samples, it is much less likely that this is due to failure to analyze organic anions such as formate or acetate, although this could be a contributory factor. The charge imbalance $\left(\Sigma^{+}-\Sigma^{-}\right)$was therefore taken as a measure of the $\mathrm{HCO}_{3}{ }^{-}$concentration in each sample. We refer to this value as $\mathrm{HCO}_{3}{ }^{*}$ to indicate that it was not measured directly.

For each site sampled, MWW concentrations and deposition fluxes of each species analyzed were determined for the snowpack as a whole and for each of three layers within it. The physical and chemical basis for definition of these layers is outlined below. Deposition fluxes $\left(\mu \mathrm{eq} \mathrm{m}^{-2}\right)$ were determined as the product of layer thickness $(\mathrm{m})$, layer density $\left(\mathrm{kg} \mathrm{m}^{-3}\right)$ and measured solute concentration $\left(\mu \mathrm{eq} \mathrm{kg}^{-1}\right)$. Fluxes are expressed in terms of deposition, rather than deposition rate, because of the uncertainty about the period over which the snowpack accumulated. MWW concentrations $\left(\mu \mathrm{eq} \mathrm{kg}^{-1}\right)$ were determined by dividing the deposition flux of solute associated with a given layer $\left(\mu \mathrm{eq} \mathrm{m}^{-2}\right)$ by the water accumulation in that layer $\left(\mathrm{kg} \mathrm{m}^{-2}\right)$.

\section{ACGUMULATION PATTERN AND PHYSICAL STRATIGRAPHY OF THE SNOW GOVER}

Snow temperatures ranged from $-3^{\circ}$ to $-21^{\circ} \mathrm{C}$, with the warmest temperatures at the top of the snowpack. There was no evidence of melting prior to sampling. Snow depths ranged from 0.43 to $0.81 \mathrm{~m}$ (mean $=0.67 \pm 0.11 \mathrm{~m})$, and the mean of all snow density measurements was $240 \pm 70 \mathrm{~kg} \mathrm{~m}^{-3}$. There was a clear correlation $\left(r^{2}=0.60, p=0.0005\right.$; Fig. $\left.2 \mathrm{a}\right)$ between snow accumulation ( $\mathrm{m}$ snow water equivalent (SWE)) and elevation $(\mathrm{m})$ :

$$
\mathrm{SWE}=0.00007 \text { elevation }+0.108 .
$$

The snowpack had a consistent physical stratigraphy that could be traced across the entire glacier (Fig. 2b). A basal layer of coarse-grained depth hoar (containing crystals up to $35 \mathrm{~mm}$ in diameter) was overlain by a loose layer of finergrained $(<4 \mathrm{~mm})$ angular crystals, and then by a hardpacked layer of fine-grained $(<1 \mathrm{~mm})$, rounded crystals. In some places, a layer of new snow $<0.13 \mathrm{~m}$ thick, in which original crystal forms could still be recognized, capped the snowpack.

At most sites, the depth-hoar layer was 0.19-0.32 m thick and there was no consistent relationship between thickness and elevation. The overlying loose, fine-grained layer thickened with increasing elevation from $0.08 \mathrm{~m}$ at $100 \mathrm{~m}$ to $0.32 \mathrm{~m}$ at $900 \mathrm{~m}$. It was absent at $1100 \mathrm{~m}$, however, where the hard-packed layer rested directly on the depth hoar. The thickness of the hard-packed layer was consistently around $0.04 \mathrm{~m}$ at elevations of $<600 \mathrm{~m}$, but it ranged from $0.025 \mathrm{~m}$ (at $800 \mathrm{~m}$ ) to a maximum of $0.16 \mathrm{~m}$ (at $1000 \mathrm{~m}$ ) at higher elevations, where it was generally better developed.
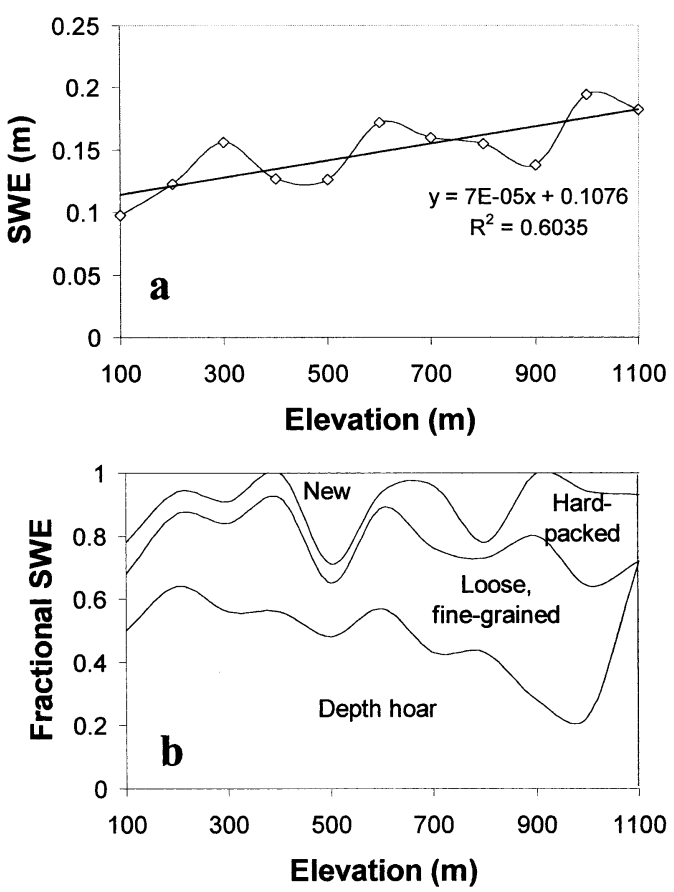

Fig. 2. (a) Snow accumulation (mw.e.) as a function of elevation on Fohn Evans Glacier, May 1995. Best-fit linear regression is also shown. (b) Physical stratigraphy of the John Evans Glacier snowpack in May 1995. Snow depth, plotted on the $y$ axis, is given in terms of fractional SWE to facilitate comparison between sites. Here zero represents the base of the snowpack. For description of layer characteristics, see text.

\section{SEASONAL PATTERN OF SNOW AGGUMULATION}

Snow-thickness measurements from the automatic weather stations were used to characterize the seasonal pattern of snow accumulation. Monthly changes in snowpack thickness were determined from UDG readings for the last day of each month. From the 4 years of record, four values were obtained for each month of the year. These were averaged, and the averages were summed over a 12 month period to generate a mean annual cycle of snowpack thickness change for each site (Fig. 3). To facilitate comparison of the three records, each thickness record was expressed as a fraction of the maximum snowpack thickness calculated for that site.

All three records show two main periods of snow accumulation (in fall and late winter/spring), separated by the summer melt season and by a period of reduced accumulation or snowpack thinning in winter. Most fall accumulation occurs in September and, to a lesser extent, October, but at UWS accumulation also occurs in August. Most spring accumulation occurs in April and May, with some accumulation in March at LWS. During the winter (November-March), changes in snowpack thickness at MWS and UWS are small. At UWS, thinning by a combination of compaction and wind scour occurs throughout the winter. At MWS, there is limited accumulation from October through December, followed by thinning in January and February. At LWS, accumulation continues throughout the winter, but at a lower rate than in fall and spring. Nevertheless, winter snowfall makes a significant contribution to the accumulation at LWS, while this contribution seems to be small at higher elevations. The main melt season occurs in June and July at all stations, but it can continue into August at LWS and, to a much lesser extent, at MWS. 


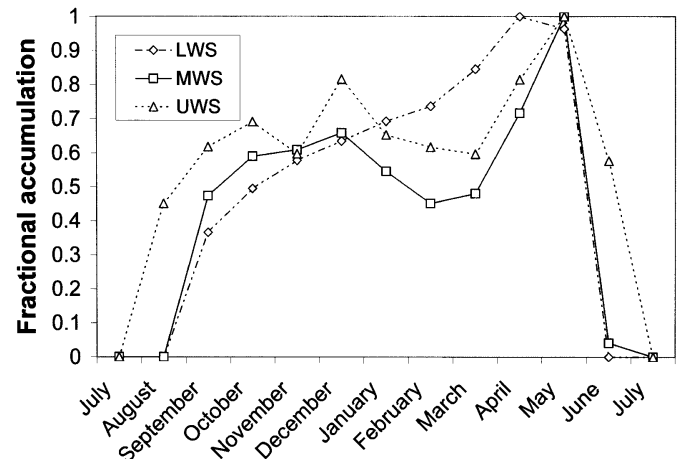

Fig. 3. Synthetic annual cycles of snow thickness at the three weather stations on Fohn Evans Glacier based on 4 years of ultrasonic depth-gauge measurements, May 1996-May 2000. Cycles were generated by summing the mean monthly change in snow thickness at each site. Results are expressed as a fraction of the maximum mean snow thickness recorded at each site.

\section{CHEMISTRY OF THE SNOW GOVER}

\section{Major-ion chemistry}

The major ions in the snow were $\mathrm{Ca}^{2+}, \mathrm{Na}^{+}, \mathrm{HCO}_{3}{ }^{*}$ and $\mathrm{Cl}^{-}$. Mean concentrations of $\mathrm{K}^{+}, \mathrm{Mg}^{2+}, \mathrm{NH}_{4}{ }^{+}, \mathrm{H}^{+}, \mathrm{NO}_{3}{ }^{-}$ and $\mathrm{SO}_{4}{ }^{2-}$ were typically one to two orders of magnitude lower than mean concentrations of these four major ions (Table 1). However, variability in ion concentrations was large, with standard deviations often $>100 \%$ of the mean concentration. Minimum measured concentrations of all species were near or below detection limits, while maximum measured concentrations were usually an order of magnitude higher than the mean.

To elucidate associations between species, a Varimax

Table 1. MWW concentrations ( $\mu e q L^{-1}$ ) of major ions in snow at John Evans Glacier, May 1995

\begin{tabular}{llrrrrrrrrrr}
\hline Layer & & $\mathrm{Na}^{+}$ & $\mathrm{Cl}$ & $\mathrm{Mg}^{2+}$ & $\mathrm{H}^{+}$ & $\mathrm{NH}_{4}^{+}$ & $\mathrm{NO}_{3}{ }^{-}$ & $\mathrm{SO}_{4}{ }^{2-}$ & $K^{+}$ & $\mathrm{Ca}^{2+}$ \\
\hline \multirow{2}{*}{ L1 } & & & & & & & & & \\
& Mean & 3.0 & 3.1 & 1.5 & 3.9 & 0.8 & 0.2 & 1.0 & 0.8 & 8.2 \\
& SD & 1.4 & 1.3 & 0.7 & 1.0 & 0.4 & 0.1 & 0.5 & 1.1 & 5.1 \\
& Max. & 5.6 & 5.7 & 2.9 & 6.1 & 1.6 & 0.4 & 2.0 & 3.6 & 21.9 \\
& Min. & 1.2 & 1.4 & 0.5 & 2.3 & 0.1 & 0.0 & 0.3 & 0.0 & 3.5 \\
& Mean & 22.6 & 22.8 & 6.0 & 3.0 & 0.7 & 0.6 & 6.8 & 0.5 & 11.3 \\
& SD & 9.0 & 5.8 & 3.1 & 1.6 & 1.0 & 0.8 & 2.9 & 0.4 & 6.2 \\
& Max. & 43.0 & 32.2 & 13.3 & 6.2 & 3.2 & 2.1 & 11.9 & 1.2 & 25.6 \\
& Min. & 11.3 & 15.9 & 1.4 & 1.3 & 0.0 & 0.0 & 3.6 & 0.0 & 3.0 \\
& Mean & 5.7 & 5.0 & 2.7 & 5.3 & 0.8 & 0.8 & 3.9 & 0.3 & 11.2 \\
& SD & 4.5 & 2.4 & 2.9 & 2.6 & 0.4 & 0.5 & 1.2 & 0.4 & 10.9 \\
& Max. & 17.4 & 11.5 & 10.7 & 11.4 & 1.4 & 1.6 & 6.5 & 1.5 & 41.8 \\
& Min. & 2.2 & 2.7 & 1.0 & 2.3 & 0.2 & 0.0 & 2.5 & 0.0 & 3.9 \\
WS & Mean & 7.6 & 7.0 & 2.7 & 4.1 & 0.8 & 0.4 & 3.2 & 0.5 & 9.3 \\
& SD & 2.3 & 1.9 & 1.1 & 0.9 & 0.3 & 0.2 & 1.2 & 0.4 & 4.7 \\
& Max. & 11.7 & 9.6 & 4.8 & 5.8 & 1.2 & 0.6 & 6.1 & 1.3 & 21.1 \\
& Min. & 3.8 & 3.4 & 1.0 & 2.4 & 0.3 & 0.1 & 2.1 & 0.2 & 4.0 \\
Raw & Mean & 8.0 & 7.2 & 2.9 & 4.0 & 0.8 & 0.4 & 3.3 & 0.7 & 10.1 \\
& SD & 11.2 & 9.1 & 3.6 & 2.4 & 0.9 & 0.7 & 4.3 & 2.1 & 10.5 \\
& Max. & 61.4 & 53.2 & 18.9 & 14.5 & 4.3 & 3.2 & 35.6 & 15.4 & 0.6 \\
& Min. & 0.0 & 0.0 & 0.0 & 0.3 & 0.0 & 0.0 & 0.0 & 0.0 & 65.9
\end{tabular}

Notes: Results are presented for the whole snowpack (WS), and individual layers within the snowpack, where L1 is the basal layer deposited in fall, L2 is the winter layer and L3 is the spring layer. Values presented are the mean, standard deviation, maximum and minimum of the 11 values obtained from snow pits dug at $100 \mathrm{~m}$ elevation intervals between 100 and $1100 \mathrm{~m}$ a.s.l. For comparison, descriptive statistics are also presented for the 115 raw analyses conducted. rotated principal-components analysis (PCA) was performed on the 115 observations of 12 variables. This identified three components with eigenvalues of $>1$, which explained $67 \%$ of the variance in the original dataset.

PCl had loadings of $>0.7$ on $\mathrm{Na}^{+}, \mathrm{Cl}^{-}, \mathrm{Mg}^{2+}$ and $\mathrm{SO}_{4}{ }^{2-}$, and appears to represent a mixture of sea salt and sulphate aerosol.

PC2 had loadings of $>0.9$ on $\mathrm{Ca}^{2+}$ and $\mathrm{HCO}_{3}{ }^{*}$, and appears to represent soil dust of predominantly carbonate composition.

PC3 had loadings of $>0.7$ on $\mathrm{H}^{+}$and $\mathrm{NO}_{3}{ }^{-}$, and of 0.39 on $\mathrm{SO}_{4}{ }^{2-}$, and seems to represent an acid aerosol component that has not been neutralized.

$\mathrm{NH}_{4}{ }^{+}$and $\mathrm{K}^{+}$did not load strongly on any of these factors.

\section{Seasonal variations in snow chemistry}

The variation in concentration of $\mathrm{Na}^{+}, \mathrm{Cl}^{-}, \mathrm{H}^{+}, \mathrm{SO}_{4}{ }^{2-}$, $\mathrm{NO}_{3}{ }^{-}$and $\mathrm{Ca}^{2+}$ with depth in the snowpack is shown for sites at 500 and $1000 \mathrm{~m}$ (Fig. 4). These species are plotted, because they characterize the three main components of the solute load identified by PCA. The major features of the records are:

(i) A well-defined peak in the concentration of $\mathrm{Na}^{+}, \mathrm{Cl}$ and $\mathrm{SO}_{4}{ }^{2-}$ at mid-depths within the snowpack splits it into three distinct layers. Below this peak, concentrations of these three species are generally low, though somewhat variable. Above it, they are also low, but more uniform. At $500 \mathrm{~m}$, concentrations in the upper layer are higher than in the basal layer, whereas at $1000 \mathrm{~m}$ they are similar to, or lower than, concentrations in the basal layer (Fig. $4 \mathrm{a}-\mathrm{c}$ and $\mathrm{g}-\mathrm{i}$ ).

(ii) $\mathrm{H}^{+}$displays a sawtooth concentration profile, with highest concentrations at the base of the snowpack and near the surface, separated by a broad minimum at mid-depths. In general terms, the $\mathrm{H}^{+}$concentration minimum coincides with the peak in concentrations of $\mathrm{Na}^{+}, \mathrm{Cl}^{-}$and $\mathrm{SO}_{4}{ }^{2-}$ (Fig. 4d and j), perhaps suggesting that acid sulphate aerosol has been neutralized by reaction with sea-salt aerosol (see Equation (4) below).

(iii) $\mathrm{NO}_{3}{ }^{-}$concentration profiles are erratic, with many samples producing concentrations below the detection limit. At $500 \mathrm{~m}$, a peak in $\mathrm{NO}_{3}{ }^{-}$concentration at the surface of the snowpack coincides with the upper peak in $\mathrm{H}^{+}$concentration. At $1000 \mathrm{~m}$, however, the highest levels are associated with the peak in concentrations of $\mathrm{Na}^{+}, \mathrm{Cl}^{-}$and $\mathrm{SO}_{4}{ }^{2-}$ (Fig. 4e and k). The erratic nature of the $\mathrm{NO}_{3}{ }^{-}$profiles, and the large number of analyses below detection limit may be evidence of $\mathrm{NO}_{3}{ }^{-}$loss by remobilization from ageing surface strata that were exposed to the atmosphere for long periods of time without significant fresh snow cover (Wolff, 1995). This is most likely to have occurred during the winter at higher elevations on the glacier, where UDG records suggest that snowfall is very limited.

(iv) $\mathrm{Ca}^{2+}$ concentrations show a series of peaks superimposed on a relatively high background, but no clear seasonal cycle (Fig. 4f and l).

Contour maps showing the concentration of individual ionic species as a function of elevation and depth within the 

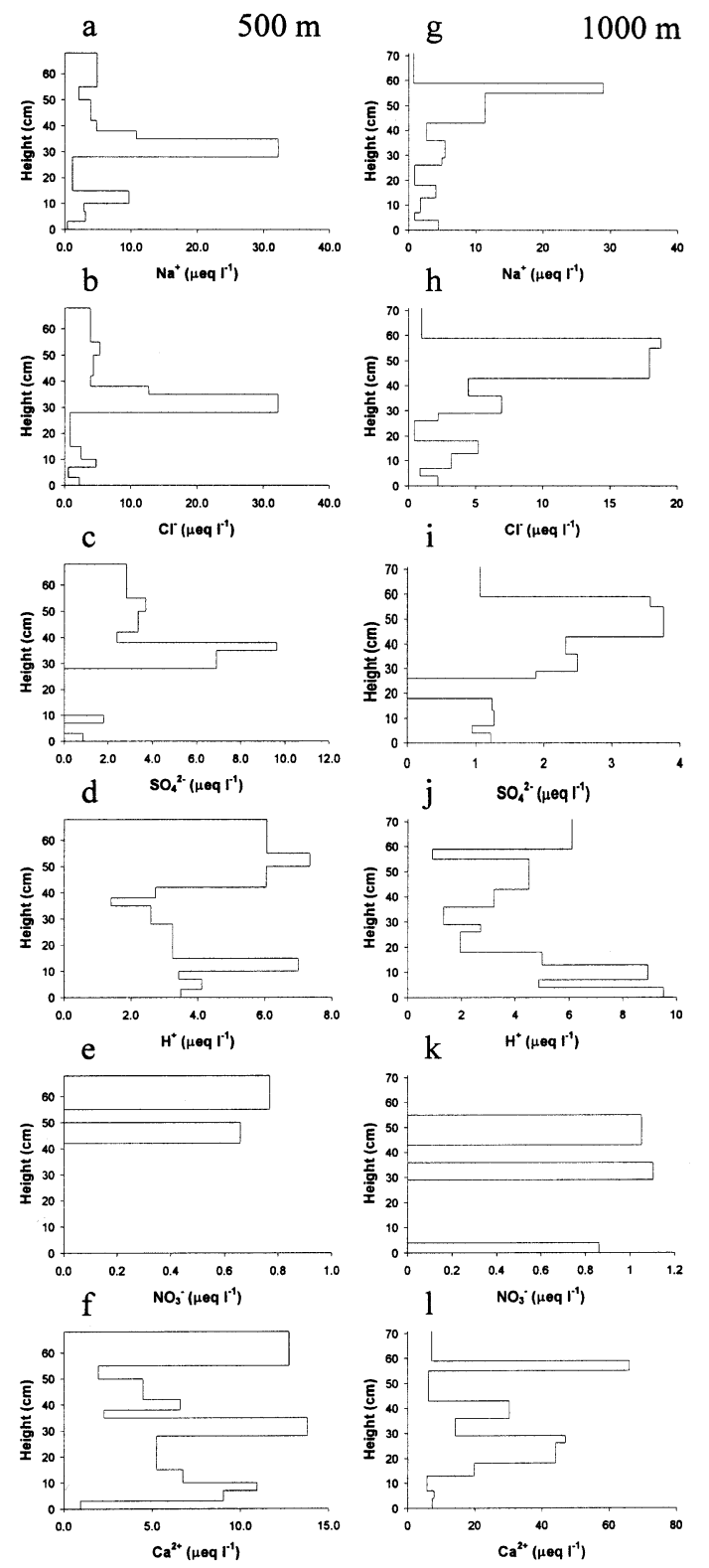

Fig. 4. Plots of the variation in concentration of major ions with depth in the snowpack at sites at $500 \mathrm{~m}(a-f)$ and $1000 \mathrm{~m}$ ( $\mathrm{g}-\mathrm{l}$ ) on Fohn Evans Glacier, May 1995. For site locations, see Figure 1.

snowpack were produced using the software package Surfer 7 (Fig. 5). Maps were also produced for the scores on each of the three leading principal components of the solute load. Raw data were gridded using triangulation and linear interpolation, and the grid was subjected to matrix smoothing prior to contouring. To facilitate comparison between sites, snow depth (plotted on the $y$ axis) is expressed as a fraction of the SWE accumulated at each site at the time of sampling. Values range from 0.0 at the base of the snowpack to 1.0 at the surface.

The main features identified in the concentration profiles for sites at 500 and $1000 \mathrm{~m}$ elevation can be traced across the whole glacier. Maps for $\mathrm{Na}^{+}, \mathrm{Cl}^{-}, \mathrm{Mg}^{2+}$ and $\mathrm{SO}_{4}{ }^{2-}$ (Fig. $5 \mathrm{a}-\mathrm{C}$ and e) show a distinct layer with high solute concentrations that occurs progressively deeper in the snowpack at higher elevations on the glacier. This layer clearly splits the snowpack into three distinct horizons, and is also the major feature of the map for PCl (Fig. 5d). Below it, concentrations of all four species decrease sharply. Above it, $\mathrm{Na}^{+}, \mathrm{Cl}^{-}$and $\mathrm{Mg}^{2+}$ show a similarly strong reduction in concentrations, but the drop in $\mathrm{SO}_{4}{ }^{2-}$ concentration is less marked (Fig. $5 e$ ). Within the layer underlying the solute-rich layer, concentrations of $\mathrm{Na}^{+}$and $\mathrm{Cl}^{-}$and scores for PCl tend to be higher at sites below $500 \mathrm{~m}$ elevation. Within the surface layer, however, concentrations of these species tend to be higher at sites above $600 \mathrm{~m}$ (Fig. 5a, b and d).

Clear seasonality is also apparent in the maps for $\mathrm{H}^{+}$, $\mathrm{NO}_{3}{ }^{-}$and PC3 (Fig. 5f-h), which show a well-defined peak in the surface layers of the snowpack. This peak occurs above the layer rich in $\mathrm{Na}^{+}, \mathrm{Cl}^{-}, \mathrm{Mg}^{2+}$ and $\mathrm{SO}_{4}{ }^{2-}$. Concentrations of $\mathrm{H}^{+}$and $\mathrm{NO}_{3}{ }^{-}$are very low within the latter layer, but increase again towards the base of the snowpack. Concentrations of $\mathrm{SO}_{4}{ }^{2-}$ remain relatively high within the layer rich in $\mathrm{H}^{+}$and $\mathrm{NO}_{3}{ }^{-}$, which likely accounts for the weak loading of PC3 on $\mathrm{SO}_{4}{ }^{2-}$.

As with concentration profiles for individual sites (Fig. 4f and 1), the maps for $\mathrm{Ca}^{2+}$ and PC2 show no clear seasonal variation (Fig. 5i and k). Instead, they depict a series of $\mathrm{Ca}^{2+}$-rich layers within the snowpack and a clear tendency for $\mathrm{Ca}^{2+}$ concentrations to be higher throughout the thickness of the snowpack at sites above $700 \mathrm{~m}$ elevation. Whether the individual layers can be correlated across the glacier is not clear.

\section{Chemical stratigraphy of the snowpack}

The concentration profiles and contour maps suggest a simple, three-fold chemo-stratigraphic subdivision of the snowpack. The three layers are readily separated on the basis of the scores for each sample on PCl. Only the intermediate layer has scores of $>+0.5$ (Fig. $5 d$ ).

Layer 1, the basal layer, constitutes progressively less of the snowpack at higher elevations on the glacier. At $100 \mathrm{~m}$ it makes up $\sim 70 \%$ of the snowpack water equivalent, but this drops to $\sim 40 \%$ at $900 \mathrm{~m}$. It is characterized by very low MWW concentrations of major ions and moderate acidity (typically $2-7 \mu \mathrm{eq} \mathrm{L}^{-1}$ of $\mathrm{H}^{+}$).

Layer 2 occurs at mid-depths within the snowpack, and its fractional thickness is relatively uniform. Because the fractional thickness of layer 1 decreases with increasing elevation, layer 2 occurs progressively closer to the base of the snowpack at higher elevations. It is characterized by high MWW concentrations of $\mathrm{Na}^{+}, \mathrm{Cl}^{-}, \mathrm{Mg}^{2+}$ and $\mathrm{SO}_{4}{ }^{2-}\left(13-40 \mu \mathrm{eq} \mathrm{L}{ }^{-1}\right.$ of $\mathrm{Na}^{+}$and $\mathrm{Cl}^{-}, 3-12 \mu \mathrm{eq} \mathrm{L}{ }^{-1}$ of $\mathrm{SO}_{4}{ }^{2-}$ ) and, except at 100 and $200 \mathrm{~m}$, by low MWW concentrations of $\mathrm{H}^{+}\left(1-6 \mu \mathrm{eq} \mathrm{L}{ }^{-1}\right)$ and $\mathrm{NO}_{3}{ }^{-}\left(0-2 \mu \mathrm{eq} \mathrm{L}{ }^{-1}\right)$.

Layer 3 occurs at the top of the snowpack and is proportionally thicker at higher elevations. It is characterized by high MWW concentrations of $\mathrm{H}^{+}$and $\mathrm{NO}_{3}{ }^{-}$(up to $11 \mu \mathrm{eq} \mathrm{L}^{-1}$ of $\mathrm{H}^{+}$and $1.6 \mu \mathrm{eq} \mathrm{L}^{-1}$ of $\mathrm{NO}_{3}{ }^{-}$), and by intermediate MWW concentrations of $\mathrm{SO}_{4}{ }^{2-}\left(2-12 \mu \mathrm{eq} \mathrm{L}{ }^{-1}\right)$.

\section{Influence of accumulation and surface elevation on solute concentration}

Analyses of spatial variability in snowpack chemistry can shed light on the large-scale controls on atmospheric deposition. Potential controls include glacio-meteorological parameters such as snow accumulation, air temperature and wind speed. Snow accumulation affects the potential for post-depositional remobilization of species such as $\mathrm{NO}_{3}{ }^{-}$, and the concentration of species deposited by dry deposition. Temperature can affect the efficiency of wet deposition, and the occurrence of riming. 

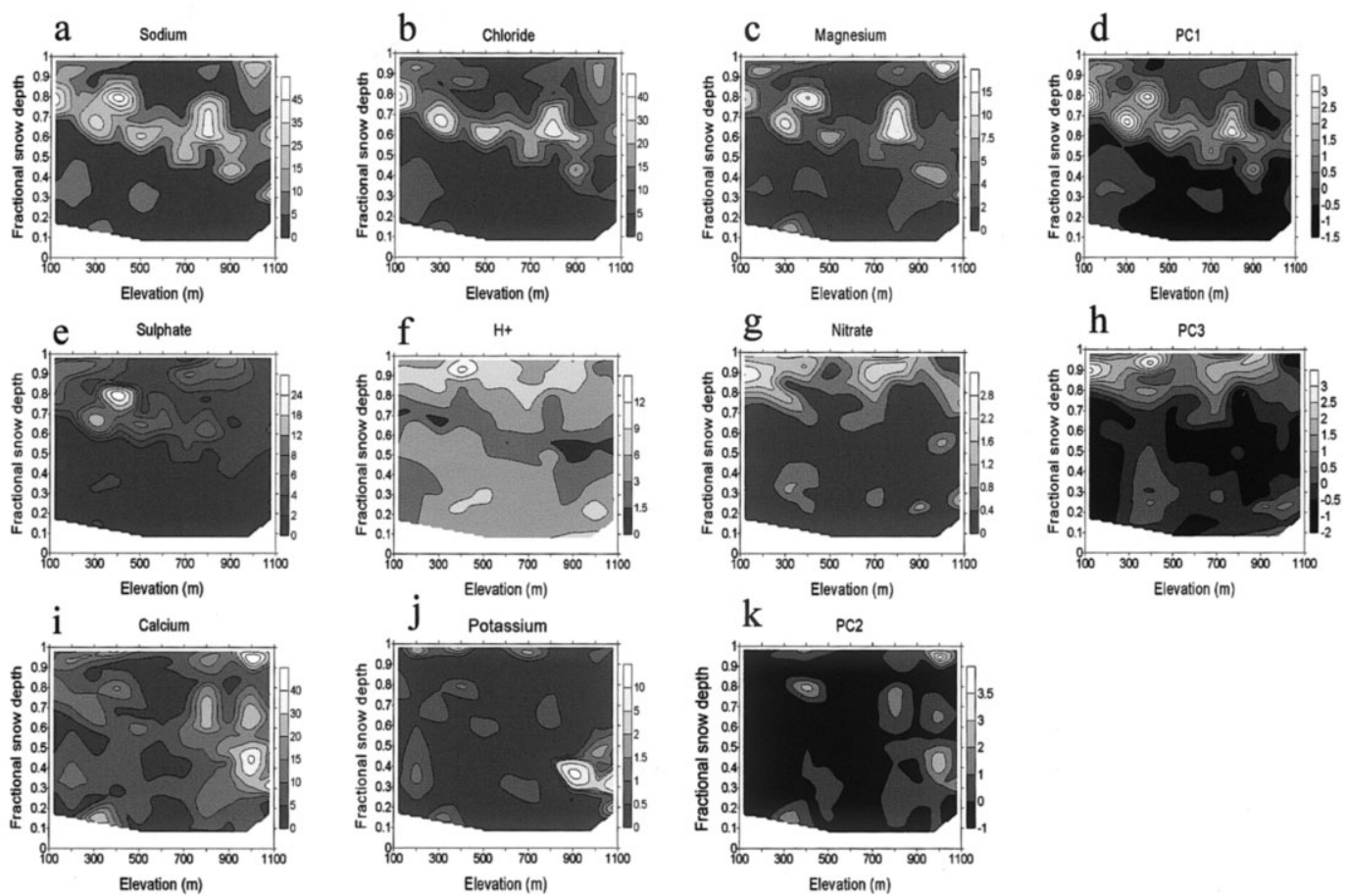

Fig. 5. Contour maps showing the variation in the concentration $\left(\mu e q L^{-1}\right)$ of major ions and in scores for the three leading principal components of the solute load as a function of elevation and fractional water equivalent snow depth, Fohn Evans Glacier, May 1995. On the $y$ axis, 0 represents the base of the snowpack and 1 the snow surface at the time of sampling. Maps of component scores are plotted next to maps of concentrations of ions that load most heavily on that component, but see text for interpretation of components.

This is important because $\mathrm{SO}_{4}{ }^{2-}$ concentrations in rime may be enhanced 5-7 times relative to typical fresh-snow values (Bergin and others, 1995). Wind speed determines the extent of reworking of the original depositional stratigraphy, ventilation of the snowpack, the occurrence of scavenging and sublimation from drifting snow, and the mobilization of soil dust from local extra-glacial sources.

Surface elevation may also be an important influence. A surface-based temperature inversion is a characteristic feature of Arctic areas, especially during the polar night (Bradley and others, 1992; Kahl and others, 1992), and is a major influence on the distribution of pollutants within the lower troposphere (Bridgman and others, 1989). Inversions tend to break down during the passage of frontal systems that bring precipitation to the High Arctic, and inversion thickness and frequency tend to decrease in the period April-September (Bradley and others, 1992; Kahl and others, 1992). This may result in both seasonal and shorter-term changes in the concentration and composition of the aerosol in the atmosphere overlying the glacier.

To evaluate the potential impact of such controls on the chemistry of the snowpack, the relationships between MWW solute concentration, accumulation and surface elevation were investigated. Although total SWE increases systematically with increasing elevation (Fig. 2a), the bulk of this variation occurs within layer 3 . Linear regression indicates that, both in the snowpack as a whole and in its three constituent layers, the MWW concentration of almost all species is independent of the accumulation rate (Table 2). Exceptions to this are $\mathrm{SO}_{4}{ }^{2-}$, for which solute concentration is inversely related to the accumulation rate in layer 2 and positively correlated with it in layer 1 , and $\mathrm{Ca}^{2+}$, for which solute concentration and accumulation rate are positively correlated in layer 1 and probably also in the whole snowpack.

A simple model, proposed by Fischer and Wagenbach
(1996), was used to analyze these relationships between MWW solute concentration and accumulation:

$$
C_{\mathrm{s}}=C_{\mathrm{p}}+\frac{C_{\mathrm{a}} V_{\mathrm{d}}}{A}+C_{\mathrm{r}} \frac{\Delta A}{A} .
$$

Here $C_{\mathrm{s}}$ is the solute concentration in snow, $C_{\mathrm{p}}$ is the concentration in precipitation, $C_{\mathrm{a}}$ is the concentration in air, $C_{\mathrm{r}}$ is the concentration in rime, $V_{\mathrm{d}}$ is the dry-deposition velocity, $A$ is the snow-accumulation rate, and $\Delta A$ is the surface rime-accumulation rate.

To make use of this model, it is first necessary to determine whether non-precipitating events (e.g. dry deposition or riming) contribute significantly to solute deposition. Fischer and Wagenbach (1996) suggested that the contribution of these processes to solute deposition could be defined by the intercept of a linear regression of the deposition flux of a given solute species on the snow-accumulation rate (Table 3). For the whole snowpack, positive intercepts were found for $\mathrm{Na}^{+}, \mathrm{Cl}^{-}, \mathrm{H}^{+}, \mathrm{SO}_{4}{ }^{2-}$ and $\mathrm{NO}_{3}{ }^{-}$. This suggests that dry deposition and/or riming may contribute to the deposition of these species. For other species, wet deposition likely dominates solute deposition on the glacier. For species with positive intercepts, the regression relationships listed in Table 3 were used to estimate the critical accumulation rate, at which wet deposition and deposition from non-precipitating events are equal. For $\mathrm{H}^{+}$and $\mathrm{Cl}^{-}$, values of critical accumulation were substantially less than ambient accumulation rates $(\sim 0.15 \mathrm{~m})$, indicating that deposition by non-precipitating events is relatively minor. For $\mathrm{Na}^{+}$, however, the two values were similar, and for $\mathrm{SO}_{4}{ }^{2-}$ and $\mathrm{NO}_{3}{ }^{-}$the critical accumulation rate was higher than ambient accumulation rates. Thus, deposition by non-precipitating events is probably significant for $\mathrm{SO}_{4}{ }^{2-}, \mathrm{NO}_{3}{ }^{-}$and $\mathrm{Na}^{+}$.

According to the model presented above, the inverse relationship between $\mathrm{MWW} \mathrm{SO}_{4}{ }^{2-}$ concentration and accumulation in layer 2 is most simply explained as a product of 
dilution of spatially uniform deposition by non-precipitating events by spatially variable accumulation. Given that deposition by non-precipitating events also seems to be significant for $\mathrm{Na}^{+}$and $\mathrm{NO}_{3}{ }^{-}$, however, the MWW concentration of these species should also be inversely related to the accumulation rate. This is in fact the case for layers 2 and 3 , and for the whole snowpack, but none of the relationships are statistically significant (Table 2).

For those species for which the regression intercepts are negative, wet deposition is apparently the dominant deposition process, and for most of these species there is no significant correlation between MWW solute concentrations and the accumulation rate. According to Equation (3), this implies that, for these species, $C_{\mathrm{p}}$ is essentially uniform across the glacier. For $\mathrm{Ca}^{2+}$ in layer 1, however, the MWW solute concentration increases with the accumulation rate. This suggests that, for this species, either $C_{\mathrm{p}}$ varies positively with snow accumulation, or deposition from non-precipitating events is significant only in areas of high accumulation. Concentrations of $\mathrm{Ca}^{2+}$ are clearly much higher at sites above $800 \mathrm{~m}$ elevation than at sites lower on the glacier (Fig. 5), suggesting that this pattern may be explained by localized dry

Table 2. Results of linear regression of the $M W W$ concentration of major ions ( $\mu$ eq $L^{-1}$ ) on snow accumulation ( $m$ w.e.) and elevation (m) for 11 sites on Fohn Evans Glacier, May 1995

\begin{tabular}{|c|c|c|c|c|c|c|c|}
\hline \multirow[b]{2}{*}{ Species } & \multirow[b]{2}{*}{ Layer } & \multicolumn{3}{|c|}{ vs accumulation } & \multicolumn{3}{|c|}{ vs elevation } \\
\hline & & Intercept & Slope & $r^{2}$ & Intercept & Slope & $r^{2}$ \\
\hline \multirow[t]{4}{*}{$\mathrm{Na}^{+}$} & $\mathrm{Ll}$ & 0.7 & 28.5 & 0.21 & 3.1 & 0.000 & 0.00 \\
\hline & L2 & 24.1 & -55.9 & 0.00 & 22.4 & 0.000 & 0.00 \\
\hline & L3 & 6.8 & -31.1 & 0.02 & 1.5 & 0.007 & 0.26 \\
\hline & WS & 11.2 & -24.5 & 0.09 & 8.0 & -0.001 & 0.01 \\
\hline \multirow[t]{4}{*}{$\mathrm{Cl}^{-}$} & $\mathrm{Ll}$ & 1.0 & 24.9 & 0.18 & 3.2 & 0.000 & 0.00 \\
\hline & L2 & 23.3 & -18.8 & 0.00 & 24.8 & -0.003 & 0.04 \\
\hline & L3 & 4.9 & 3.0 & 0.00 & 2.5 & 0.004 & $0.36^{* *}$ \\
\hline & WS & 8.5 & -10.5 & 0.02 & 7.2 & 0.000 & 0.00 \\
\hline \multirow[t]{4}{*}{$\mathrm{Mg}^{2+}$} & Ll & 0.2 & 15.3 & 0.21 & 1.1 & 0.001 & 0.11 \\
\hline & L2 & 7.2 & -47.0 & 0.02 & 7.4 & -0.002 & 0.06 \\
\hline & L3 & 3.8 & -27.6 & 0.04 & 0.4 & 0.003 & 0.21 \\
\hline & WS & 2.4 & 1.8 & 0.002 & 2.5 & 0.000 & 0.01 \\
\hline \multirow[t]{4}{*}{$\mathrm{H}^{+}$} & Ll & 4.0 & -1.1 & 0.00 & 4.0 & 0.000 & 0.00 \\
\hline & L2 & 4.5 & -57.0 & 0.11 & 4.3 & -0.002 & 0.20 \\
\hline & L3 & 5.1 & 6.7 & 0.00 & 6.4 & -0.002 & 0.05 \\
\hline & WS & 4.6 & -3.2 & 0.00 & 4.4 & 0.000 & 0.03 \\
\hline \multirow[t]{4}{*}{$\mathrm{NH}_{4}^{+}$} & $\mathrm{L} 1$ & 0.5 & 3.2 & 0.04 & 1.0 & 0.000 & 0.07 \\
\hline & L2 & 1.4 & -26.7 & 0.07 & 1.0 & 0.000 & 0.03 \\
\hline & L3 & 0.6 & 5.0 & 0.09 & 0.6 & 0.000 & 0.10 \\
\hline & WS & 0.5 & 2.4 & 0.05 & 0.9 & 0.000 & 0.05 \\
\hline \multirow[t]{4}{*}{$\mathrm{NO}_{3}{ }^{-}$} & $\mathrm{Ll}$ & 0.1 & 1.2 & 0.04 & 0.2 & 0.000 & 0.01 \\
\hline & L2 & 1.1 & -18.6 & 0.06 & 1.4 & -0.001 & $0.37^{* *}$ \\
\hline & L3 & 1.1 & -8.2 & 0.11 & 1.3 & -0.001 & $0.37^{* *}$ \\
\hline & WS & 0.7 & -1.9 & 0.10 & 0.6 & -0.0003 & $0.29^{*}$ \\
\hline \multirow[t]{4}{*}{$\mathrm{SO}_{4}{ }^{2-}$} & $\mathrm{Ll}$ & -0.2 & 14.3 & $0.35^{*}$ & 1.0 & 0.000 & 0.00 \\
\hline & L2 & 10.8 & -158.0 & $0.27^{*}$ & 11.1 & -0.007 & $0.67^{* *}$ \\
\hline & L3 & 2.9 & 26.4 & 0.19 & 3.5 & 0.001 & 0.03 \\
\hline & WS & 5.8 & -17.6 & 0.18 & 4.0 & -0.001 & 0.14 \\
\hline \multirow[t]{4}{*}{$\mathrm{K}^{+}$} & Ll & 1.7 & -11.7 & 0.05 & -0.3 & 0.001 & $0.29^{*}$ \\
\hline & L2 & 0.6 & -4.4 & 0.01 & 1.0 & -0.001 & $0.46^{* *}$ \\
\hline & L3 & 0.6 & -7.7 & 0.15 & 0.5 & 0.000 & 0.03 \\
\hline & WS & 0.4 & 1.3 & 0.00 & 0.2 & 0.001 & $0.27^{*}$ \\
\hline \multirow[t]{4}{*}{$\mathrm{Ca}^{2+}$} & $\mathrm{Ll}$ & -3.9 & 145.6 & $0.39^{* *}$ & 3.4 & 0.008 & $0.27^{*}$ \\
\hline & L2 & 12.6 & -49.2 & 0.005 & 12.9 & -0.003 & 0.02 \\
\hline & L3 & 16.3 & -133.7 & 0.06 & 2.6 & 0.014 & 0.19 \\
\hline & WS & -3.1 & 84.1 & 0.25 & 5.2 & 0.007 & 0.22 \\
\hline
\end{tabular}

Notes: Results are presented for the whole snowpack (WS) and for three chemically distinct layers within it (L1, L2, L3). Statistically significant relationships are indicated in bold ${ }^{* *}$ indicates relationship significant at $p=0.05 ;{ }^{*}$ indicates relationship significant at $p=0.1$. deposition of soil dust at high elevations, where wind speeds are relatively high. This would be maximized in the fall, when local rock surfaces are not yet fully covered by snow.

Since accumulation and elevation are positively correlated, relationships between the MWW concentrations of most species and elevation are similar to those between concentration and accumulation (Table 2). However, there are significant inverse relationships between the concentration of $\mathrm{NO}_{3}{ }^{-}$and elevation in layers 2 and 3 and in the whole snowpack. As discussed above, this is probably due to dilution of nitrate deposited by dry deposition and/or riming by snowfall that increases with elevation (note that nitrate deposition is independent of elevation in these layers; Table 3). There are also significant positive relationships between $\mathrm{K}^{+}$and elevation for layer 1 and the whole snowpack, and a significant inverse relationship for layer 2. For layer 1 and

Table 3. Results of linear regression of the atmospheric deposition of major ions $\left(\mu e \mathrm{~m} \mathrm{~m}^{-2}\right.$ ) on snow accumulation ( $m$ w.e.) and elevation ( $m$ ) for 11 sites on fohn Evans Glacier, May 1995

$\begin{array}{cccc}\text { vs accumulation } & \text { Critical } & \text { vs elevation } \\ \text { Species Layer Intercept Slope } r^{2} & \text { accumulation Intercept Slope } & r^{2}\end{array}$

\begin{tabular}{|c|c|c|c|c|c|c|c|c|}
\hline \multirow[t]{4}{*}{$\mathrm{Na}^{+}$} & L1 & -177.0 & 5300 & $0.53^{* *}$ & & 241.4 & 0.036 & 0.005 \\
\hline & L2 & 104.0 & 20859 & $0.36^{* *}$ & & 521.5 & 0.087 & 0.01 \\
\hline & L3 & NA & NA & NA & & -19.5 & 0.380 & $0.72^{* *}$ \\
\hline & WS & 515.0 & 4010 & 0.10 & 0.128 & 743.4 & 0.500 & 0.21 \\
\hline \multirow[t]{4}{*}{$\mathrm{Cl}^{-}$} & L1 & -185.0 & 5431 & $0.57^{* *}$ & & 258.6 & 0.012 & 0.00 \\
\hline & $\mathrm{L} 2$ & 172.0 & 15225 & $0.31^{*}$ & & 551.1 & 0.050 & 0.00 \\
\hline & L3 & 33.0 & 4340 & $0.64^{* *}$ & & 11.7 & 0.310 & $0.82^{* *}$ \\
\hline & WS & 116.0 & 6149 & $0.3^{*}$ & 0.019 & 821.4 & 0.370 & 0.21 \\
\hline \multirow[t]{4}{*}{$\mathrm{Mg}^{2+}$} & $\mathrm{Ll}$ & -131.0 & 3170 & $0.57^{* *}$ & & 74.4 & 0.096 & 0.12 \\
\hline & L2 & 39.0 & 5118 & 0.19 & & 170.2 & -0.035 & 0.01 \\
\hline & L3 & NA & NA & NA & & -14.2 & 0.180 & $0.57^{* *}$ \\
\hline & WS & -12.0 & 2757 & 0.17 & & 230.4 & 0.240 & 0.17 \\
\hline \multirow[t]{4}{*}{$\mathrm{H}^{+}$} & $\mathrm{Ll}$ & -0.3 & 3891 & $0.53^{* *}$ & & 306.0 & 0.028 & 0.006 \\
\hline & L2 & 3.3 & 2799 & $0.36^{* *}$ & & 70.7 & 0.002 & 0.00 \\
\hline & L3 & 6.7 & 5274 & $0.64^{* *}$ & & 129.6 & 0.130 & 0.10 \\
\hline & WS & 155.0 & 3040 & $0.3^{*}$ & 0.051 & 506.3 & 0.160 & 0.11 \\
\hline \multirow[t]{4}{*}{$\mathrm{NH}_{4}{ }^{+}$} & L1 & -21.0 & 1076 & $0.36^{* *}$ & & 79.2 & -0.018 & 0.02 \\
\hline & L2 & -3.1 & 793 & 0.20 & & 10.8 & 0.007 & 0.02 \\
\hline & L3 & -5.4 & 1033 & $0.57^{* *}$ & & 6.7 & 0.046 & $0.29^{*}$ \\
\hline & WS & -58.0 & 1199 & $0.4^{* *}$ & & 96.7 & 0.035 & 0.04 \\
\hline \multirow[t]{4}{*}{$\mathrm{NO}_{3}{ }^{-}$} & $\mathrm{Ll}$ & -12.0 & 328 & $0.27^{*}$ & & 12.5 & 0.004 & 0.01 \\
\hline & L2 & -2.1 & 673 & 0.14 & & 24.4 & -0.018 & 0.11 \\
\hline & L3 & -0.7 & 712 & $0.39^{* *}$ & & 22.6 & 0.006 & 0.01 \\
\hline & WS & 39.0 & 120 & 0.02 & 0.320 & 59.5 & -0.008 & 0.01 \\
\hline \multirow[t]{4}{*}{$\mathrm{SO}_{4}{ }^{2-}$} & $\mathrm{L} 1$ & -104.0 & 2339 & $0.68^{* *}$ & & 83.5 & 0.012 & 0.00 \\
\hline & $\mathrm{L} 2$ & -9.4 & 8467 & 0.25 & & 233.0 & -0.120 & $0.3^{*}$ \\
\hline & L3 & -19.0 & 4777 & $0.82^{* *}$ & & 49.6 & 0.190 & $0.33^{*}$ \\
\hline & WS & 415.0 & 312 & 0.01 & 1.330 & 366.1 & 0.080 & 0.06 \\
\hline \multirow[t]{4}{*}{$\mathrm{K}^{+}$} & Ll & 37.0 & 268 & 0.01 & & -25.6 & 0.140 & $0.4^{* *}$ \\
\hline & $\mathrm{L} 2$ & 1.6 & 416 & 0.18 & & 20.6 & -0.014 & 0.24 \\
\hline & L3 & 7.3 & 80 & 0.03 & & 7.8 & 0.004 & 0.02 \\
\hline & WS & -56.0 & 932 & 0.17 & & 2.8 & 0.130 & $0.44^{* *}$ \\
\hline \multirow[t]{4}{*}{$\mathrm{Ca}^{2+}$} & Ll & -1272.0 & 24325 & $0.58^{* *}$ & & 172.1 & 0.960 & 0.21 \\
\hline & $\mathrm{L} 2$ & 65.0 & 9330 & 0.25 & & 262.7 & 0.038 & 0.01 \\
\hline & L3 & NA & NA & NA & & -58.1 & 0.730 & $0.63^{* *}$ \\
\hline & WS & -1875.0 & 22343 & $0.42^{* *}$ & & 376.7 & 1.730 & $0.33^{*}$ \\
\hline
\end{tabular}

Notes: Results are presented for the whole snowpack (WS) and for three chemically distinct layers within it (L1, L2, L3). Statistically significant relationships are indicated in bold ${ }^{* *}$ indicates relationship significant at $p=0.05 ;{ }^{*}$ indicates relationship significant at $p=0.1$. NA indicates that it was not appropriate to perform a linear regression analysis on the data because of the existence of bidirectional relationships between the variables. For the snow-accumulation case, the intercept provides a measure of deposition from non-precipitating events, and the slope provides a measure of the solute concentration $\left(\mu \mathrm{eq} \mathrm{m}^{-3}\right)$ in new snow. Where the intercept for the whole snowpack is positive, the critical accumulation ( $\mathrm{m}$ w.e.) defines the magnitude of the accumulation at which the wet-deposition flux is equal to the intercept. 
the whole snowpack, these relationships are best explained as the result of localized inputs of soil dust at high elevations in the fall, when potential source areas are not yet fully snow-covered. For layer 2, the inverse relationship reflects variable dilution of a more uniform dust deposition (Table 3) within a snow layer that thickens as elevation increases. Finally, there is a significant positive correlation between the concentration of $\mathrm{Cl}^{-}$and elevation in layer 3. This is a result of unusually high $\mathrm{Cl}^{-}$concentrations in snow at the sample sites at 800 and $1000 \mathrm{~m}$ elevation, which result in very high $\mathrm{Cl}^{-}$deposition at these elevations (Table 3).

\section{Influence of snow accumulation and elevation on atmospheric deposition to the snowpack}

Atmospheric deposition of almost all species tends to increase with snow accumulation (Table 3). In the snowpack as a whole, this tendency is statistically significant for species for which wet deposition dominates $\left(\mathrm{H}^{+}, \mathrm{NH}_{4}{ }^{+}\right.$and $\left.\mathrm{Cl}^{-}\right)$and for $\mathrm{Ca}^{2+}$, for which locally high rates of deposition from non-precipitating events may occur at high elevations where accumulation is also high. It is not significant for those species for which deposition from non-precipitating events is believed to be significant at all elevations $\left(\mathrm{Na}^{+}, \mathrm{NO}_{3}{ }^{-}\right.$and $\left.\mathrm{SO}_{4}{ }^{2-}\right)$ (Table 3). However, statistically significant relationships do exist for these species (and $\mathrm{Mg}^{2+}$ ) within individual layers. In general, these results indicate that wet deposition is an important means of deposition of most species to the snowpack throughout the accumulation period. In layer 2, however, deposition of $\mathrm{SO}_{4}{ }^{2-}$ and $\mathrm{NO}_{3}{ }^{-}$is independent of the accumulation rate, consistent with the suggestion that deposition by non-precipitating events may be important for these species in winter (Table 3 ).

Although accumulation increases with elevation, $\mathrm{Ca}^{2+}$ and $\mathrm{K}^{+}$are the only species for which deposition is positively related to elevation in the snowpack as a whole. This seems to reflect localized inputs of soil dust at high elevations. Within layer 3, which thickens rapidly with increasing elevation, however, deposition of $\mathrm{Na}^{+}, \mathrm{Cl}^{-}, \mathrm{Mg}^{2+}, \mathrm{NH}_{4}{ }^{+}, \mathrm{SO}_{4}{ }^{2-}$ and $\mathrm{Ca}^{2+}$ is significantly positively correlated with elevation, presumably because wet deposition of these species increases with accumulation in late winter and spring.

\section{Comparisons between seasonal trends in snow chemistry and air chemistry at Alert}

The consistent glacier-wide chemical stratigraphy of the snowpack likely reflects a seasonal cycle in the chemistry of the atmosphere overlying the glacier. Although there are no local measurements of aerosol chemistry, measurements have been made continuously since 1980 at Alert $\left(82.5^{\circ} \mathrm{N}, 62.3^{\circ} \mathrm{W}\right)$ on the northern tip of Ellesmere Island (Sirois and Barrie, 1999). These measurements define the seasonal variation in weekly concentrations of individual aerosol constituents, and of aerosol components derived by positive matrix factorization (Norman and others, 1999; Sirois and Barrie, 1999). They can therefore be used to assist interpretation of the seasonal cycle in snowpack chemistry at John Evans Glacier.

$\mathrm{SO}_{4}{ }^{2-}, \mathrm{NO}_{3}{ }^{-}, \mathrm{H}^{+}, \mathrm{NH}_{4}{ }^{+}, \mathrm{K}^{+}, \mathrm{Na}^{+}$and $\mathrm{Cl}^{-}$show a distinct seasonal cycle in atmospheric concentration, while $\mathrm{Ca}^{2+}$ does not. For $\mathrm{Mg}^{2+}$, the cycle is rather weak (Sirois and Barrie, 1999). However, the form and timing of the concentration peaks and intervening troughs vary between species. Chloride peaks in January, while $\mathrm{Na}^{+}$displays a broad peak from January through March. Sulphate, $\mathrm{H}^{+}$and
$\mathrm{NH}_{4}{ }^{+}$peak in late March and April, while $\mathrm{NO}_{3}{ }^{-}$and $\mathrm{K}^{+}$ have broad peaks lasting from January through April or May. All these species reach minimum concentrations in the atmosphere during the summer months (June-September), though for $\mathrm{Cl}^{-}$the seasonal minimum begins as early as April or May. These seasonal cycles result from a sharp seasonal variation in the atmospheric residence time of aerosols, which is on the order of 3-7 weeks in winter and 3-7 days in summer. This variation results from seasonal changes in atmospheric circulation and in the efficiency with which precipitation removes aerosols from the atmosphere (Barrie, 1986; Sirois and Barrie, 1999).

By combining knowledge of the seasonal variation in aerosol chemistry at Alert and of the seasonal pattern of snow accumulation on the glacier, it is possible to offer an interpretation of the chemical stratigraphy of the snowpack at John Evans Glacier. The fall accumulation period occurs from August through October, when atmospheric concentrations of most aerosol constituents are at their seasonal minimum. It thus seems likely that layer 1, which occurs at the base of the snowpack and which contains very low concentrations of most solute species, represents snow that accumulated during the fall. Especially at higher elevations, this layer does contain significant amounts of $\mathrm{Ca}^{2+}$, which is probably associated with soil-derived dust. This is consistent with the observation that atmospheric $\mathrm{Ca}^{2+}$ concentrations at Alert show minimal seasonal variation, with perhaps a weak peak associated with locally derived dust in September/October when extra-glacial surfaces are not yet fully snow-covered (Sirois and Barrie, 1999).

Layer 2 is characterized by high concentrations of $\mathrm{Na}^{+}$, $\mathrm{Cl}^{-}, \mathrm{Mg}^{2+}$ and $\mathrm{SO}_{4}{ }^{2-}$, all of which reach peak atmospheric concentrations during the period January-April. However, aerosol $\mathrm{Cl}^{-}$peaks earlier and more sharply than the other species, and its atmospheric concentration falls from January onwards (Sirois and Barrie, 1999). In the snowpack too, the $\mathrm{Cl}^{-}$concentration peak is narrower than the $\mathrm{Na}^{+}$and $\mathrm{SO}_{4}{ }^{2-}$ peaks, and it tends to be located at the base of layer 2, while the peaks for the other species are often displaced towards the top of the layer (Fig. 5a, b and e). The similarity between the seasonal patterns of variation in the concentration of these species in the atmosphere and the snowpack strongly suggests that layer 2 represents snow accumulated during the winter and early spring, probably up until about early April.

Layer 3 is distinctly more acid than layer 2 and it is characterized by peaks in the concentration of $\mathrm{H}^{+}$and $\mathrm{NO}_{3}{ }^{-}$, and by relatively high levels of $\mathrm{SO}_{4}{ }^{2-}$ and low concentrations of $\mathrm{Na}^{+}$and $\mathrm{Cl}^{-}$. This change in snowpack chemistry is consistent with interpretations of changes in the provenance of $\mathrm{SO}_{4}{ }^{2-}$ in the atmospheric aerosol between late winter and spring (Norman and others, 1999). In February and March, $60-90 \%$ of the $\mathrm{SO}_{4}{ }^{2-}$ is associated with aerosol components designated as sea salt, mixed photo-S/sea salt, and anthropogenic S. By mid-April, these components account for only about $20 \%$ of the atmospheric $\mathrm{SO}_{4}{ }^{2-}$, most of which is then associated with an aerosol component designated as photo-S (Norman and others, 1999; Sirois and Barrie, 1999).

Photo-S is predominantly sulphuric acid formed by in situ gas-to-particle conversion of anthropogenic $\mathrm{SO}_{2}$ at polar sunrise. It peaks in April. Anthro-S consists of nonacidic salts of $\mathrm{SO}_{4}{ }^{2-}$, with $\mathrm{NH}_{4}{ }^{+}$as the dominant cation. It peaks from January to March. Mixed photo-S/sea salt consists of non-acidic $\mathrm{SO}_{4}{ }^{2-}$, with $\mathrm{Na}^{+}, \mathrm{Mg}^{2+}$ and $\mathrm{NH}_{4}{ }^{+}$as the dominant cations (Sirois and Barrie, 1999). The lack of $\mathrm{Cl}^{-}$in 
this component likely results from reactions between sulphuric acid and sea salt that displace $\mathrm{H}^{+}$and $\mathrm{Cl}^{-}$as $\mathrm{HCl}$ gas (Brimblecombe and Clegg, 1988):

$$
\mathrm{H}_{2} \mathrm{SO}_{4}+2 \mathrm{NaCl} \rightarrow 2 \mathrm{HCl}(\text { gas })+\mathrm{Na}_{2} \mathrm{SO}_{4} .
$$

The mixed photo-S/sea-salt component has a broad seasonal peak that reflects the variation in the photo-S and seasalt components of the aerosol. The sea-salt component that is unmodified by Reaction (4) peaks from December to February (Sirois and Barrie, 1999). It seems likely that Reaction (4) explains the association between $\mathrm{SO}_{4}{ }^{2-}$ and sea-salt species in layer 2 of the snowpack, and the generally low concentrations of $\mathrm{H}^{+}$in that layer.

Comparison of the chemistry of layer 2 with the aerosol chemistry at Alert is consistent with its containing $\mathrm{SO}_{4}{ }^{2-}$ derived from a mixture of sources including the sea-salt, anthro-S and mixed photo-S/sea-salt components of the atmospheric aerosol. This would suggest that layer 2 was deposited between December and March. By contrast, the chemistry of layer 3 suggests that photo-S is likely the dominant source of $\mathrm{SO}_{4}{ }^{2-}$ in this layer, and that it was therefore deposited in April and May. If these inferences about the timing of layer deposition are correct, the difference in $\mathrm{NO}_{3}{ }^{-}$concentrations between layers 2 and 3 is not readily explained in terms of the seasonal cycle in the composition of the atmospheric aerosol at Alert, because $\mathrm{NO}_{3}{ }^{-}$is present in the atmosphere throughout the winter. Instead it seems more likely to be due to differences in the extent of postdepositional remobilization of $\mathrm{NO}_{3}{ }^{-}$from the snowpack. This is likely to be enhanced in winter, when accumulation rates are low and snow surfaces may be exposed to the atmosphere for prolonged periods of time (Wolff, 1995). High concentrations of $\mathrm{NO}_{3}{ }^{-}$in surface snow may thus reflect both the recent occurrence of deposition and higher rates of accumulation that limit the duration of surface exposure to the atmosphere.

\section{Interpretation of the physico-chemical stratigraphy of the snowpack}

Comparison of the physical (Fig. 2b) and chemical stratigraphy of the snowpack (layers 1-3; Fig. 5) suggests that the two are closely associated. To a first approximation, layer 1 is coincident with the depth-hoar layer, layer 2 with the loose, fine-grained layer, and layer 3 with the hard-packed layer and overlying fresh snow. However, there are exceptions to this generalization. For instance, at 100 and $200 \mathrm{~m}$, the boundary between layers 1 and 2 follows the top of the loose, fine-grained layer, while above $700 \mathrm{~m}$ it occurs within the lower part of this layer. While at most sites the boundary between layers 2 and 3 lies near or at the top of the loose, fine-grained layer, at 100 and $200 \mathrm{~m}$ it coincides with the top of the hard-packed layer, making layer 2 coincident with the hard-packed layer. At 1000 m, it lies within the hardpacked layer.

Given the chemistry of the depth-hoar layer and its occurrence at the base of the snowpack, it almost certainly represents initially coarse-grained snow that fell during the fall accumulation period. This snow would then have experienced temperature-gradient metamorphism during the intense and prolonged cold of the polar night (when air temperatures on the glacier drop to $-40^{\circ} \mathrm{C}$ or lower). However, one problem with this interpretation is that whilst the fractional thickness of the depth-hoar layer decreases with increasing elevation, the UDG results suggest that the rela- tive importance of fall accumulation is greater at higher elevations. For example, the snowpack thickness at the end of September represents 35\% of the maximum thickness at the LWS, $47 \%$ at the MWS and $61 \%$ at the UWS (Fig. 3). By contrast, the depth hoar represents $50 \%$ of the water equivalent thickness at $100 \mathrm{~m}$ elevation and only $23 \%$ at $1000 \mathrm{~m}$ (Fig. 2b). This apparent inconsistency can be explained if the upper part of the fall snow accumulation was extensively reworked by the wind during the winter months and incorporated into the overlying loose, finegrained layer. The observation that the upper boundary of layer 1 is sometimes located within or at the top of the loose, fine-grained layer strongly suggests that snow with a chemistry typical of the depth-hoar layer has been incorporated into the base of the loose, fine-grained layer.

This implies that the loose, fine-grained layer is likely a mixture of snow that fell during the winter months and snow that was reworked by wind from the underlying depth-hoar layer. Both the fractional thinning of the depth-hoar layer at higher elevations and the UDG measurements (which show thinning of the snowpack over winter at the upper and middle weather stations) suggest that the input from wind reworking was likely maximized at these elevations.

The hard-packed layer normally occurs entirely within layer 3. However, at 100 and $200 \mathrm{~m}$ it is found entirely within layer 2. This likely reflects the incorporation of solute-rich snow from layer 2 into the hard-packed layer by wind reworking. Layer 3 and the hard-packed layer plus overlying new snow show elevation-dependent patterns of thickness variation similar to the spring snow accumulation measured by UDG. The fractional change in snowpack thickness between the end of March and the end of May is $15 \%$ of the annual maximum thickness at LWS, $54 \%$ at MWS and $40 \%$ at UWS. At elevations of 200-400 m, the hard-packed layer plus new snow represents $8-16 \%$ of the snowpack water equivalent. Above $700 \mathrm{~m}$, it represents 20-36\%. Layer 3 constitutes $11 \%$ of the snowpack water equivalent at $100 \mathrm{~m}$, but as much as $40 \%$ at 700 and $900 \mathrm{~m}$. This supports the idea that these layers represent predominantly spring snowfall that, at some sites, has been mixed by the wind with snow from the underlying loose, fine-grained layer. The hard-packed nature of the layer may result from wind packing and/or radiation-induced metamorphism following polar sunrise (which occurs in mid-March at this site).

\section{CONGLUSIONS}

The John Evans Glacier snowpack has a tripartite physical structure that can be traced across the entire glacier, and that is closely matched by a tripartite chemical stratigraphy. A basal layer of solute-poor depth hoar represents snow that accumulated in the fall and resisted wind reworking in the winter. It is overlain by a layer of loose, fine-grained snow that contains relatively high concentrations of solute species derived from the sea-salt, anthro-S and mixed photo-S/seasalt components of the atmospheric aerosol. Nitrate concentrations in this layer are generally low, probably due to the effects of post-depositional remobilization. This layer is interpreted to be a mixture of winter snowfall and snow reworked by wind from the underlying depth hoar. The wind contribution is likely greatest at higher elevations on the glacier.

A hard-packed layer that is overlain by new snow caps the snowpack. It contains relatively high concentrations of $\mathrm{H}^{+}$ 
and $\mathrm{SO}_{4}{ }^{2-}$, probably derived from the photo-S component of the atmospheric aerosol that is produced by gas-particle conversion of $\mathrm{SO}_{2}$ to sulphuric acid after polar sunrise. It thus represents the spring accumulation on the glacier. It also contains high concentrations of $\mathrm{NO}_{3}{ }^{-}$, probably because the young age of the snow and enhanced rates of accumulation in spring reduce the extent of post-depositional remobilization relative to the winter layer.

For most solute species, atmospheric deposition increases with snow accumulation, and solute concentration is largely independent of accumulation and elevation. For these species, deposition occurs primarily by wet deposition. Exceptions to this pattern include $\mathrm{Ca}^{2+}$ and $\mathrm{K}^{+}$, for which there is evidence for locally high inputs from dry deposition of soil dust at higher elevations where wind speeds are probably higher than lower on the glacier. These inputs are most marked in the fall, when local source areas are still not fully snow-covered. Concentrations of $\mathrm{SO}_{4}{ }^{2-}$ are inversely associated with accumulation, implying a significant input from non-precipitating events (such as dry deposition and riming) that is differentially diluted by snow accumulation. This behaviour is most marked in the winter layer of the snowpack. Non-precipitating events may also contribute significantly to the deposition of $\mathrm{NO}_{3}{ }^{-}$, but concentrations of this species are not inversely related to accumulation. This may be a result of post-depositional remobilization from the snow surface, the extent of which is inversely related to the accumulation rate. For $\mathrm{SO}_{4}{ }^{2-}$ and $\mathrm{NO}_{3}{ }^{-}$, rates of deposition to the snowpack as a whole are independent of the rate of snow accumulation, largely because of the importance of deposition from nonprecipitating events in winter.

\section{AGKNOWLEDGEMENTS}

Supported by the Natural Sciences and Engineering Research Council of Canada, the University of Alberta Central Research Fund, and a C-BAR grant to Skidmore. Logistic support was provided by Polar Continental Shelf Project, Natural Resources Canada (PCSP/EPCP Contribution 02997). Research permission was kindly granted by the Nunavut Research Institute and by the peoples of Grise Fjord and Resolute Bay. J. Woodward and the late P. M. Wolfe, to whose memory this paper is dedicated, provided field assistance. A. Arendt established the weather stations on the glacier. We thank M. Tranter, R. M. Koerner, D. Wagenbach and an anonymous referee for comments on an earlier draft, and M. A. Lange for his editorial work on the paper.

\section{REFERENCES}

Barrie, L. A. 1986. Arctic air pollution: an overview of current knowledge. Atmos. Environ., 20(4), 643-663.

Barrie, L. A., D. A. Fisher and R. M. Koerner. 1985. Twentieth century trends in Arctic air pollution revealed by conductivity and acidity observations in snow and ice in the Canadian High Arctic. Atmos. Environ., 19(12), 2055-2063.

Bergin, M. H. and 8 others. 1995. The contributions of snow, fog, and dry deposition to the summer flux of anions and cations at Summit, Greenland. 7. Geophys. Res., 100 (D8), 16,275-16,288.

Boutron, C. F. 1995. Historical reconstruction of the Earth's past atmospheric environment from Greenland and Antarctic snow and ice cores. Env. Rev., 3, 1-28.
Bradley, R. S., F.T. Keimig and H. F. Diaz. 1992. Climatology of surfacebased inversions in the North American Arctic. 7. Geophys. Res., 97(D14), 15,699-15,712.

Bridgman, H. A., R. C. Schnell, J. D. Kahl, G. A. Herbert and E. Joranger. 1989. A major haze event near Point Barrow, Alaska: analysis of probable source regions and transport pathways. Atmos. Environ., 23(11), 2537-2549.

Brimblecombe, P. and S. L. Clegg. 1988. The solubility of acid gases in marine aerosols. Atmos. Chem., 7, 1-18.

Copland, L. and M. Sharp. 2001. Mapping thermal and hydrological conditions beneath a polythermal glacier with radio-echo sounding. F. Glaciol., 47(157), 232-242.

Davidson, C. I., J. R. Harrington, M. J. Stephenson, M. J. Small, F. P. Boscoe and R. E. Gandley. 1989. Seasonal variations in sulfate, nitrate and chloride in the Greenland ice sheet: relation to atmospheric concentrations. Atmos. Environ., 23(11), 2483-2493.

Fischer, H. and D. Wagenbach. 1996. Large-scale spatial trends in recent firn chemistry along an east--west transect through central Greenland. Atmos. Environ., 30(19), 3227-3238.

Fisher, D. A., R. M. Koerner and N. Reeh. 1995. Holocene climatic records from Agassiz Ice Cap, Ellesmere Island, N.W.T., Canada. Holocene, 5(1), 19-24.

Goto-Azuma, K., R. M. Koerner, M. Nakawo and A. Kudo. 1997. Snow chemistry of Agassiz Ice Cap, Ellesmere Island, Northwest Territories, Canada. F. Glaciol., 43(144), 199-206.

Grumet, N. S., C. P. Wake, G. A. Zielinski, D. Fisher, R. Koerner and J. D. Jacobs. 1998. Preservation of glaciochemical time series in snow and ice from the Penny Ice Cap, Baffin Island. Geophys. Res. Lett., 25(3), 357-360.

Jonsson, S. and M. Hansson. 1990. Identification of annual layers in superimposed ice from Storöyjökulen in northeastern Svalbard. Geogr. Ann., 72A (1), 41-54.

Kahl, J. D., M. C. Serreze and R. C. Schnell. 1992. Tropospheric low-level temperature inversions in the Canadian Arctic. Atmosphere-Ocean, 30 (4), 511-529.

Kerr, J.W. 1972. Geology, Dobbin Bay, District of Franklin. Ottawa, Ont., Geological Survey of Canada. (Map 1358A, scale 1:250 000.)

Koerner, R. M. 1977. Devon Island ice cap: core stratigraphy and paleoclimate. Science, 196(4285), 15-18.

Koerner, R. M. and D. A. Fisher. 1982. Acid snow in the Canadian High Arctic. Nature, 295(5845), 137-140.

Koerner, R. M. and W. S. B. Paterson. 1974. Analysis of a core through the Meighen Ice Cap, Arctic Canada, and its paleoclimatic implications. Quat. Res., 4(3), 253-263.

Legrand, M. R., C. Lorius, N. I. Barkov and V. N. Petrov. 1988. Vostok (Antarctica) ice core: atmospheric chemistry changes over the last climatic cycle (160,000 years). Atmos. Environ., 22(2), 317-331.

Mayewski, P. A. and 7 others. 1986. Sulfate and nitrate concentrations from a south Greenland ice core. Science, 232(4753), 975-977.

Mayewski, P. A., M. J. Spencer, W. B. Lyons and M. Twickler. 1987. Seasonal and spatial trends in South Greenland snow chemistry. Atmos. Environ., $21(4), 863-869$.

Mayewski, P. A. and 8 others. 1993. Greenland ice core "signal" characteristics: an expanded view of climate change. 7. Geophys. Res., 98(D7), 12,839-12,847.

Mayewski, P. A. and 13 others. 1994. Changes in atmospheric circulation and ocean ice cover over the North Atlantic during the last 41,000 years. Science, 263(5154), 1747-1751.

Neftel, A., J. Beer, H. Oeschger, F. Zürcher and R. C. Finkel. 1985. Sulphate and nitrate concentrations in snow from south Greenland, 1895-1978. Nature, 314(6012), 611-613.

Norman, A. L. and 6 others. 1999. Sources of aerosol sulphate at Alert: apportionment using stable isotopes. 7. Geophys. Res., 104(D9), 11,619-11,631.

Sirois, A. and L. A. Barrie. 1999. Arctic low tropospheric aerosol trends and composition at Alert, Canada, 1980-1995. F. Geophys. Res., 104(D9), $11,599-11,618$.

Steffensen, J. P. 1988. Analysis of the seasonal variation in dust, $\mathrm{Cl}^{-}, \mathrm{NO}_{3}{ }^{-}$, and $\mathrm{SO}_{4}{ }^{2-}$ in two central Greenland firn cores. Ann. Glaciol., 10, 171-177.

Wagenbach, D., K. O. Münnich, U. Schotterer and H. Oeschger. 1988. The anthropogenic impact on snow chemistry at Colle Gnifetti, Swiss Alps. Ann. Glaciol., 10, 183-187.

Wake, C. P. 1989. Glaciochemical investigations as a tool for determining the spatial and seasonal variation of snow accumulation in the central Karakorum, northern Pakistan. Ann. Glaciol., 13, 279-284.

Wolff, E. W. 1995. Nitrate in polar ice. In Delmas, R. J., ed. Ice core studies of global biogeochemical cycles. Berlin, etc., Springer-Verlag, 195-224. (NATO ASI Series I: Global Environmental Change 30.) 